\title{
Investigations on the cell type responsible for the endometrial secretion of complement component 3 (C3)
}

\section{P.Bischof ${ }^{1}$, D.Planas-Basset, A.Meisser and A.Campana}

Sterility and Gynaecologic Endocrinology Clinic, Department of Obstetrics and Gynaecology, University of Geneva, Maternité, 1211 Geneva 14, Switzerland

'To whom correspondence should be addressed at: Laboratoire d'Hormonologie, Maternité, 1211 Geneva 14, Switzerland

It has been shown that rat and human endometria have the capacity to produce complement component 3 (C3). In rats, endometrial $\mathrm{C} 3$ is an oestrogen-dependent protein produced and secreted by glandular cells. The cell responsible for the synthesis and secretion of human endometrial $\mathrm{C} 3$ has not been clearly defined. Our study was aimed at answering this question. Samples of endometrium obtained from hysterectomies were either immunostained for $\mathrm{C} 3$ or digested with collagenase; then the stromal and glandular cells were separated and immunopurified (or not) with an antibody to CD45 coupled to magnetic beads to eliminate the endometrial lymphomyeloid cells. Cells were cultured for 2 weeks and C3 measured in the medium by an in-house radioimmunoassay. Glandular as well as stromal cells stained positively for $\mathbf{C} 3$ and released $\mathrm{C} 3$ in vitro. The release of $\mathrm{C3}$ from both cell types could be inhibited by cycloheximide. Epithelial cells produced significantly more $\mathrm{C3}$ than stromal cells, and endometrial $\mathrm{C} 3$ production was higher for both cell types when these were obtained from secretory as compared to proliferative endometria. Lymphomyeloid cells were possibly a source of $\mathrm{C} 3$ since after immunoadsorption of these cells, the remaining stromal or glandular cells produced significantly less C3. We conclude that endometrial stromal, glandular and lymphomyeloid cells all produce $\mathbf{C 3}$.

Key words: complement component 3/endometrial cell culture/ endometriosis/intra-uterine device

\section{Introduction}

Complement component $3(\mathrm{C} 3)$ is a $\beta_{2}$-glycoprotein synthesized as pro- $\mathrm{C} 3$ by hepatocytes (major source), monocytes, fibroblasts and endothelial cells. It has a molecular mass of $180 \mathrm{kDa}$ and is composed of two non-identical polypeptide chains $(\alpha, \beta)$ held together by non-covalent interactions.

The $\alpha$ chain and the $\beta$ chain are 110 and $70 \mathrm{kDa}$ in size respectively (Bokisch et al., 1975). C3 plays a pivotal role in the process of complement activation. Binding of activated $\mathrm{C} 3$ (C3b) to non-self cell surfaces (self surfaces contain molecules which limit binding of C3b) activates a molecular complex of several other complement components $(\mathrm{C} 5-\mathrm{C} 9$ ) which becomes capable of osmotic disruption of the invading non-self cells.

Weed and Arquembourg (1980) were the first to report the presence of complement component 3 (C3) in eutopic endometria from women suffering from endometriosis. Since they could not observe $\mathrm{C} 3$ in normal endometrium they concluded that endometriosis was an autoimmune disease. In contrast to this original observation, several studies have reported the presence of $\mathrm{C} 3$ in normal endometria of fertile and infertile women (Tauber et al., 1985; Bartosik et al., 1987; Isaacson et al., 1990), with or without endometriosis.

Several studies (Komm et al., 1986; Sundstrom et al., 1989, 1990; Kuivanen et al., 1989) conducted in rats showed that the rat uterine lining produces a $180 \mathrm{kDa}$ protein recognized to be $\mathrm{C} 3$ by specific antibodies and by cDNA sequencing. This rat endometrial $\mathrm{C} 3$ is an oestrogen-dependent protein. Interestingly, rat liver C3 mRNA is not up-regulated by oestrogens. An immunohistochemical analysis of rat endometrial C3 and RNA extractions from separated epithelial and stromal cells (Sundstrom et al. , 1989) clearly attributed the origin of rat endometrial C3 to the epithelial cells. In humans, the situation seems to be different: stromal and epithelial cells purified from endometriomas and cultured separately in presence of $\left[{ }^{35} S\right]$ methionine both produced radiolabelled $\mathrm{C} 3$, but the epithelial cells were several times more active in C3 synthesis (Isaacson et al., 1989). These results confirmed a previous immunofluorescence study of $\mathrm{C} 3$ in normal and abnormal endometrium (Weed and Arquembourg, 1980) showing the presence of this complement factor in stromal as well as epithelial cells. Finally, epithelial cell monolayers of gestational endometria incorporate $\left[{ }^{35} \mathrm{~S}\right]$ methionine into immunorecognizable radioactive C3 (Fay et al., 1990). One can thus conclude from the literature that normal, abnormal (endometriomas) and gestational endometria produce C3 and that this secretion is essentially due to the epithelial cells. None of these studies, however, quantified the $\mathrm{C} 3$ contribution of the different cell types; neither are there indications about the contamination of stromal cell cultures by epithelial cells (which could explain a possible in-vitro production of $\mathrm{C} 3$ by stromal cells). Furthermore, human endometrium is not only composed of stromal and epithelial cells, as numerous lymphomyeloid cells invade the endometrium at each cycle (Bulmer et al., 1988; Vince $e t$ al., 1990) and colonize both the stromal and epithelial compartments (Pace et al., 1991). Since several of these leukocytes and particularly the macrophages are known to produce complement factors, including C3 (Colten et al., 1986), it is difficult to know if endometrial epithelial and 
stromal cells and/or endometrial leukocytes are responsible for C3 synthesis and secretion.

The purpose of the present study was to quantify by radioimmunoassay the $\mathrm{C} 3$ produced in vitro by different endometrial cell types, including stromal, epithelial and lymphomyeloid cells.

\section{Materials and methods}

\section{Cell preparation and culture}

Fresh samples of endometrial tissue were obtained from women (32-46 years of age) undergoing a hysterectomy for reasons other than malignancy (mainly for myomata) and brought to the laboratory within $1 \mathrm{~h}$ of surgery. Endometria were analysed separately by the Pathology Department and described as proliferative $(n=5)$, secretory $(n=4)$, proliferative from patients with mild peritoneal endometriosis (according to the surgeon's report; $n=2$ ) and secretory from patients bearing a non-medicated intra-uterine device (IUD; Gravigard from GD Searle; $n=2$ ). Tissues were processed and stromal and glandular cells separated and cultured as previously described (Martelli et al., 1993). Lymphomyeloid cells in the stromal and glandular cell suspensions were immunoadsorbed (or not) using a mouse monoclonal antibody against human leukocyte common antigen (anti-CD45; Dakopatts, Copenhagen, Denmark) and magnetic particles coated with a second antibody (sheep anti-mouse IgG; Dynabeads M 280, Dynal Milan Analytica, Roche, Switzerland) according to a previously published protocol (Martelli et al., 1993). Viability of the cells was assessed by the trypan blue exclusion test and never found to be $<95 \%$. Cells $\left(10^{6} / \mathrm{ml}\right)$ were cultured separately in triplicate either as purified stromal or glandular cells (not contaminated by lymphomyeloid cells) or as non-purified glandular or stromal cells (contaminated by lymphomyeloid cells).

Cultures were performed as indicated (Martelli et al., 1993) in 12-well tissue culture plates (Costar, Cambridge, MA, USA) and incubation done at $37^{\circ} \mathrm{C}$ in an atmosphere of $5 \% \mathrm{CO}_{2}$ in air in a humid incubator. Culture medium was Roswell Park Memorial Institute (RPMI) 1640 (Gibco, Basel, Switzerland) supplemented with $10 \%$ heat-inactivated fetal calf serum (FCS; Amined, Birsfelden, Switzerland), penicillin G (10 $\left.10^{6} \mathrm{IU}\right)$, $200 \mu \mathrm{g} /$ streptomycin (both from Hoechst, Darmstadt, Germany) and $2.5 \mu \mathrm{g} / \mathrm{ml}$ fugizone (Gibco); the medium was changed every other day. In some experiments, cycloheximide $(50 \mu \mathrm{g} / \mathrm{ml}$, Sigma, St Louis, MO, USA) was added to the medium on the second day of culture. Cell supernatants were stored at $-20^{\circ} \mathrm{C}$ until assayed.

\section{Immunohistochemistry}

Paraffin-embedded sections of proliferative $(n=3)$ and secretory $(n=3)$ endometria and of one implantation site of an 11 week pregnancy were obtained from the Pathology Department, University of Geneva, Switzerland. These were stained with antibodies to cytokeratin and with anti-human $\mathrm{C} 3 \mathrm{~b}$ (Jansen Biochimica, Amined Birsfelden, Switzerland) using biotinylated horse anti-mouse or anti-rabbit IgG followed by an avidin-biotin peroxidase complex according to a technique already reported (Weintraub et al., 1990). Negative controls included replacement of the primary antibody with unrelated mouse myeloma monoclonal antibody.

In order to assess the degree of purity of our cell preparations, immunohistochemistry was also performed on the cell suspensions obtained after treatment of the tissues for culture. Briefly, before plating the stromal or the glandular cells (immunopurified or not), aliquots of the cell suspensions were spun on clean microscope slides in a cytocentrifuge (Shandon, Astomore, UK). The slides were fixed in acetone, washed and stained with $50 \mu \mathrm{l}$ of a 1:20 dilution of the first antibody (monoclonal mouse anti-human) CD45, factor VIII, vimentin (all from Dakopatts, Copenhagen, Denmark), anti-cytokeratin clones AE1/AE3 (Boehringer Mannheim, Germany) and anti-cytokeratin CAM 5.2 (Becton Dickinson Inotech, Basel, Switzerland). The last two antibodies were used as a mixture $(1: 1)$ according to a method already reported (Martelli et al., 1993). The results were expressed as the number of positive cells per 300 total cells counted (percentage).

\section{Radioiodination of C3}

Purified human C3 (Calbiochem, Lucerne, Switzerland) was diluted in phosphate-buffered saline (PBS) at a final concentration of $658 \mu \mathrm{g} / \mathrm{ml}$. Aliquots of $20 \mu \mathrm{l}(13.2 \mu \mathrm{g})$ were prepared and stored at $-20^{\circ} \mathrm{C}$ until used for radioiodination or preparation of the standard curve.

After thawing, a $20 \mu$ l aliquot of C3 was radioiodinated with the lactoperoxidase technique as modified by Aubert (1977). The reagents were added in the following order: pure C3 (13.2 $\mu \mathrm{g}$ in $20 \mu \mathrm{l}$ PBS $)$, sodium acetate $(20 \mu \mathrm{l}, 0.4 \mathrm{M}, \mathrm{pH} 5.6), 1.0 \mathrm{mCi}$ of ${ }^{125} \mathrm{I}$ ( $100 \mathrm{mCi} / \mathrm{ml}$; Amersham, Zürich, Switzerland), $5 \mu \mathrm{g}$ lactoperoxidase $(10 \mu \mathrm{l}$ from a freshly prepared $0.5 \mathrm{mg} / \mathrm{ml}$ solution in the acetate buffer) and hydrogen peroxide (10 $\mu$ l of a 1:20 000 dilution). The reaction was stopped after $30 \mathrm{~s}$ by the addition of $100 \mu \mathrm{l}$ of transfer buffer $(0.01 \mathrm{M}$ phosphate, $16 \%$ sucrose, $1 \%$ potassium iodide and $0.1 \%$ sodium azide, $\mathrm{pH} \mathrm{7.6)}$ and the reaction mixture transferred to a Sepharose $\mathrm{Cl} 4 \mathrm{~B}$ column $(60 \times 1.5 \mathrm{~cm}$; Pharmacia, Uppsala, Sweden) pre-equilibrated in the assay buffer $[0.05 \mathrm{M}$ phosphate containing $0.5 \%$ bovine serum albumin (BSA) pH 7.4]. Elution was carried out with the same buffer. ${ }^{125} \mathrm{I}$-labelled C3 eluted as a single peak (around fraction $30,20 \mathrm{drops} /$ fraction) that was clearly separated from the peak of unreacted ${ }^{125}$ ( fraction 45). The fractions containing ${ }^{125}$ I-labelled C3 were pooled, aliquoted and stored at $-20^{\circ} \mathrm{C}$ until used.

\section{Radioimmunoassay of C3}

The assay was set up essentially as reported for another protein (Bischof et al., 1989) with minor modifications.

Rabbit anti-human C3b (100 $\mu \mathrm{l} /$ tube, Janssen Biochimica) at a final dilution of $1: 100000$ in the assay buffer $(0.05 \mathrm{M}$ phosphate containing $0.5 \% \mathrm{BSA}, \mathrm{pH} 7.4$ ) was preincubated for $6 \mathrm{~h}$ at room temperature with $100 \mu \mathrm{l}$ of standards (purified C3, 5-658 ng/ml) or samples to be measured. After preincubation, $100 \mu \mathrm{l}$ of ${ }^{125}$ I-labelled C3 (10 $\left.000 \mathrm{cpm}\right)$ was added to each tube and incubation continued for $16-18 \mathrm{~h}$ at room temperature. After incubation, free and antibody-bound $\mathrm{C} 3$ were separated by adding $1 \mathrm{ml}$ of immunoadsorbent (sheep anti-rabbit IgG diluted in $15 \%$ 
Table 1. Immunohistochemistry of the cell suspensions (range $\%, n=4$ )

\begin{tabular}{|c|c|c|c|c|c|}
\hline \multirow{2}{*}{$\begin{array}{l}\text { Antibodies } \\
\text { against: }\end{array}$} & \multirow[t]{2}{*}{ Cells recognized } & \multicolumn{4}{|c|}{ Immunopurification } \\
\hline & & \multicolumn{2}{|c|}{ Stromal cells } & \multicolumn{2}{|c|}{ Epithelial cells } \\
\hline Cytokeratin & Epithelial & $1-6$ & $1-4$ & $55-83$ & $75-92$ \\
\hline Factor VIII & Endothelial & ND & $0-2$ & ND & $0-2$ \\
\hline CD45 & Lymphomyeloid & $12-24$ & $0-1$ & $1-4$ & $0-1$ \\
\hline
\end{tabular}

$\mathrm{ND}=$ not determined

polyethylene glycol). After $20 \mathrm{~min}$ of incubation, the samples were centrifuged, washed and counted in an LKB 1261 Multigamma (Wallac MBV, Stäfa, Switzerland). The amount of bound radioactive ${ }^{125}$-labelled $\mathrm{C} 3$ in the pellets was compared to that obtained with the standard curve and calculated with a computer using the RIA calc programme (Wallac) based on logit $\mathrm{B} / \mathrm{Bo}$ versus the $\log$ of the concentration of cold C3. This RIA has a sensitivity limit of $3 \mathrm{ng} / \mathrm{ml}$ and intra- and inter-assay coefficients of variation of $8.6 \pm 2.0$ and $12.4 \pm 4.6 \%$ (mean $\pm \mathrm{SD}$ ) respectively. All samples including the standard curve (eight values) were run in duplicates. Results were expressed as ng of C3 per $10^{6}$ cells in culture. Statistical analysis was performed by using Student's $t$-test for paired or unpaired values when appropriate.

\section{Results}

\section{Immunohistochemistry}

Immunohistochemical analysis performed on the cell suspensions before plating allowed assessment of the degree of purity of our preparations (Table I). Before immunopurification, the stromal cell suspension was contaminated by epithelial cells $(1-6 \%)$ and by lymphomyeloid cells $(12-24 \%)$. Immunopurification eliminated all lymphomyeloid cells, but the immunopurified stromal cell suspension was still contaminated by $1-4 \%$ glandular and $0-2 \%$ endothelial cells. The glandular cell suspension was $75-92 \%$ pure after immunopurification, but was still contaminated by $2-5 \%$ stromal and $0-2 \%$ endothelial cells.

As shown in Figure 1, in proliferative endometrium antibodies to C3 diffusely stained the stromal and epithelial cells. The cytoplasm but not the nuclei of these cells was slightly stained (Figure 1A). In contrast, staining was much more intense in the cytoplasm of both cell types as well as in endothelial cells in a secretory endometrium (Figure 1B). Some decidual cells of the implantation site stained positively for $\mathrm{C} 3$ whereas both the villous and the extravillous trophoblastic cells (cytotrophoblastic cells invading the decidua) were negative. Some C3 staining was, however, visible in the fetal stroma of the trophoblastic villi (Figure 1D). Villous and extravillous trophoblast was positive for cytokeratin whereas the decidual cells were negative (Figure 1C).

\section{Cultures}

In endometria obtained during the proliferative or the secretory phase or obtained from the two women bearing an IUD, the glandular cells released significantly more $(0.001<P<0.05)$ C3 than the corresponding stromal cells. In contrast, in eutopic endometria $(n=2)$ from women with peritoneal endometriosis, the secretion of $\mathrm{C} 3$ by stromal cells was significantly higher $(0.001<P<0.03)$ than the corresponding epithelial cells (Figure 2). Glandular cells from proliferative endometria released three times more $\mathrm{C} 3$ than the stromal cells from the same endometria, whereas the glandular cells from a secretory endometrium secreted $\sim 10$ times more $\mathrm{C} 3$ than the corresponding stromal cells (Figure 2).

When $50 \mu \mathrm{g} / \mathrm{ml}$ cycloheximide was added on day 2 to the culture medium, the release of $\mathrm{C} 3$ from both glandular as well as stromal cells was significantly $(0.001<P<0.01)$ inhibited (Figure 3).

In order to compare the production rates of $\mathrm{C} 3$ among the different endometria and cell types cultured, we calculated the concentration of $\mathrm{C} 3$ produced over $24 \mathrm{~h}$ for the first 6 days of culture (Figure 4). In proliferative, secretory and IUD-bearing endometria, the $\mathrm{C} 3$ production rate was significantly $(0.001<$ $P<0.05)$ lower in stromal as compared to epithelial cells. In eutopic endometria of women with mild peritoneal endometriosis, the $\mathrm{C} 3$ production rate was similar in stromal and glandular cells (Figure 4). Irrespective of the type of cell, C3 production in proliferative endometria was significantly $(0.001<P<0.01)$ lower than in secretory endometria. Endometria bearing an IUD had a similar stromal but a significantly $(P<0.001)$ increased glandular $\mathrm{C} 3$ production when compared to secretory phase endometria. The stromal and glandular $\mathrm{C} 3$ production of eutopic endometria of women with endometriosis was significantly higher $(P<0.001)$ than in normal proliferative phase endometria (Figure 4).

During the first 2-6 days of culture, the release of C3 by immunopurified glandular and stromal cells (Figure 5 , without CD45 cells) was significantly lower $(0.005<P<0.01)$ than the release of $\mathrm{C} 3$ by non-immunopurified cells (Figure 5, with CD45 cells).

This decrease did not depend on the histological phase (proliferative, secretory, IUD or endometriosis), with one noticeable exception: purified or non-purified glandular cells from eutopic endometria of women with endometriosis secreted similar amounts of C3 throughout the 20 days of culture (Figure 5). After the 6th to 8th day of culture, immunopurified stromal cells secreted significantly $(0.001<P<0.01)$ more $\mathrm{C} 3$ than nonimmunopurified cells, irrespective of the type of endometrium 

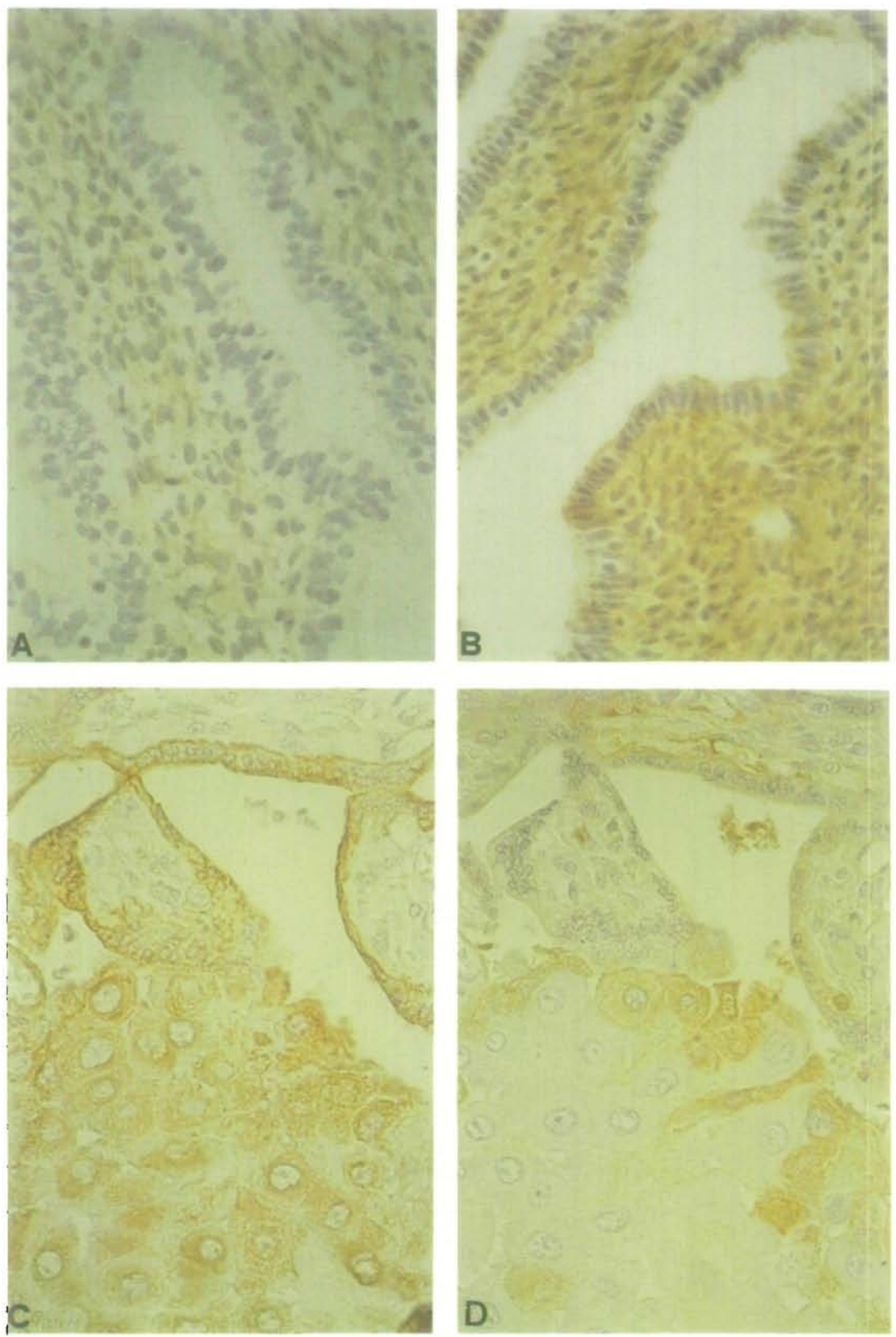

Fig. 1. Immunohistochemical distribution of C3 in a proliferative (A) and a secretory endometrium (B) and of cytokeratin (C) and C3 (D) in the implantation site of an 11 week pregnancy. Note the diffuse cytoplasmic staining in both stromal and glandular cells in $\mathbf{A}$ and the intense staining in B. Cytokeratin positivity is seen in villous trophoblast and in trophoblastic cells within the decidua (C), whereas trophoblast (villous or extravillous) is negative and some decidual cells are positive for C3 (D). 
P.Bischof et al.

\section{IN-VITRO ENDOMETRIAL C3 RELEASE}
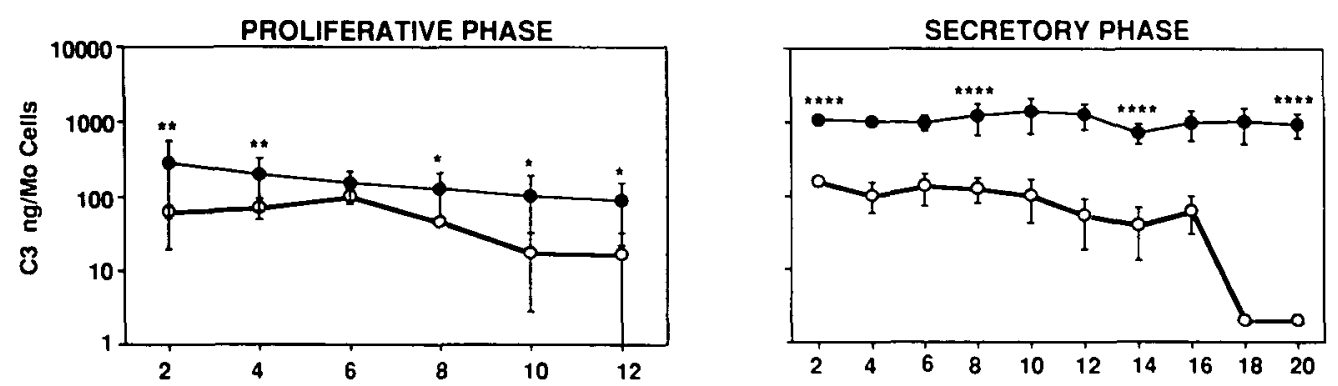

PROLIFERATIVE PHASE WITH ENDOMETRIOSIS

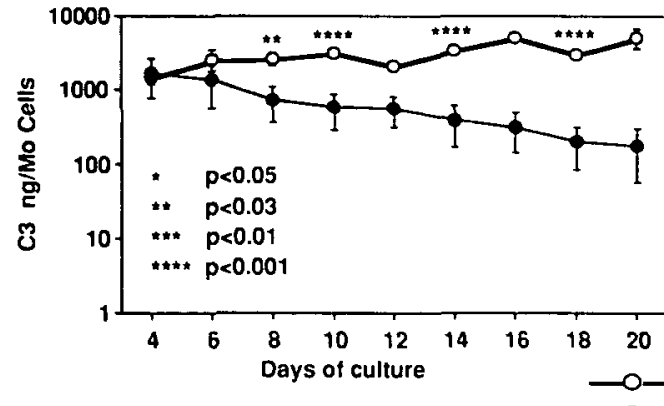

$\longrightarrow$ Stromal Cells

SECRETORY PHASE WITH IUD

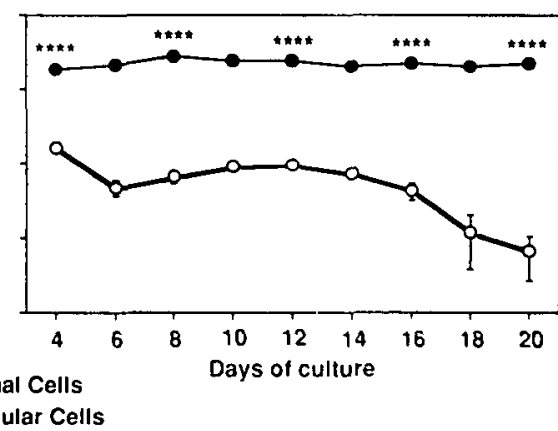

Fig. 2. Release of $\mathrm{C} 3$ in vitro by cultured stromal and glandular cells. Mo $=10^{6}$.

\section{EFFECT OF CYCLOHEXIMIDE ON ENDOMETRIAL C3 PRODUCTION}
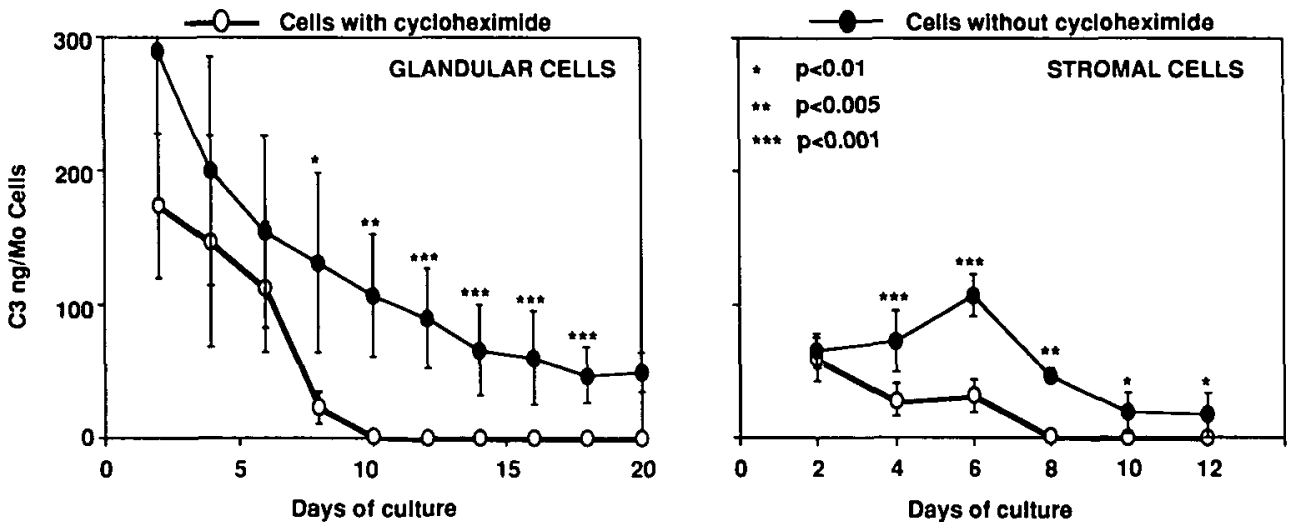

Fig. 3. Effect of cycloheximide on endometrial C3 release by stromal and glandular cells cultured in vitro. Mo $=10^{6}$.

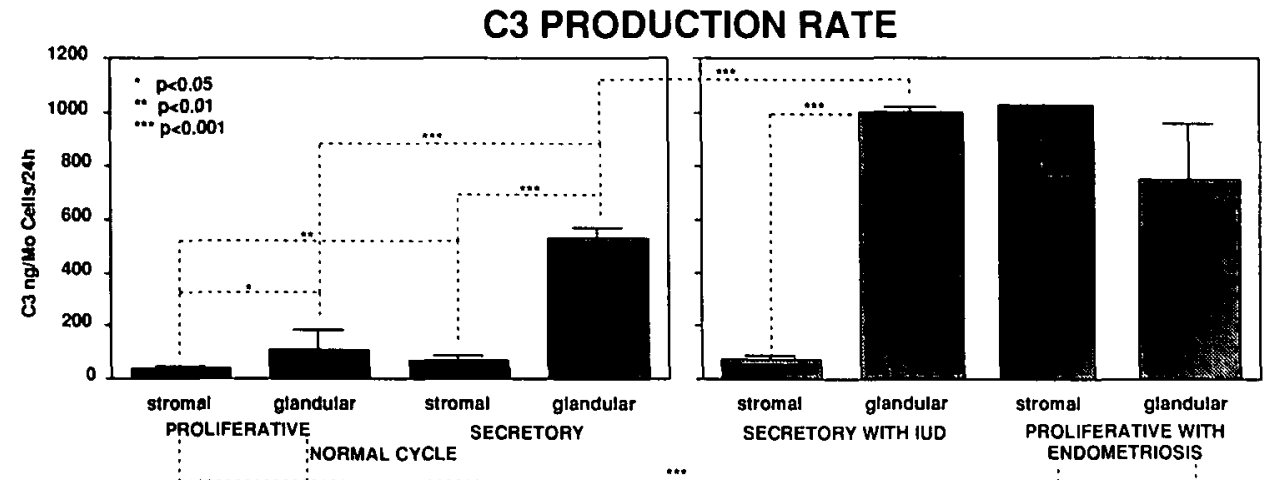

Fig. 4. Production rates of in-vitro released endometrial C 3 over the first 6 days of culture of stromal and glandular cells. 


\section{EFFECT OF CD45 CELLS ON ENDOMETRIAL C3 PRODUCTION}
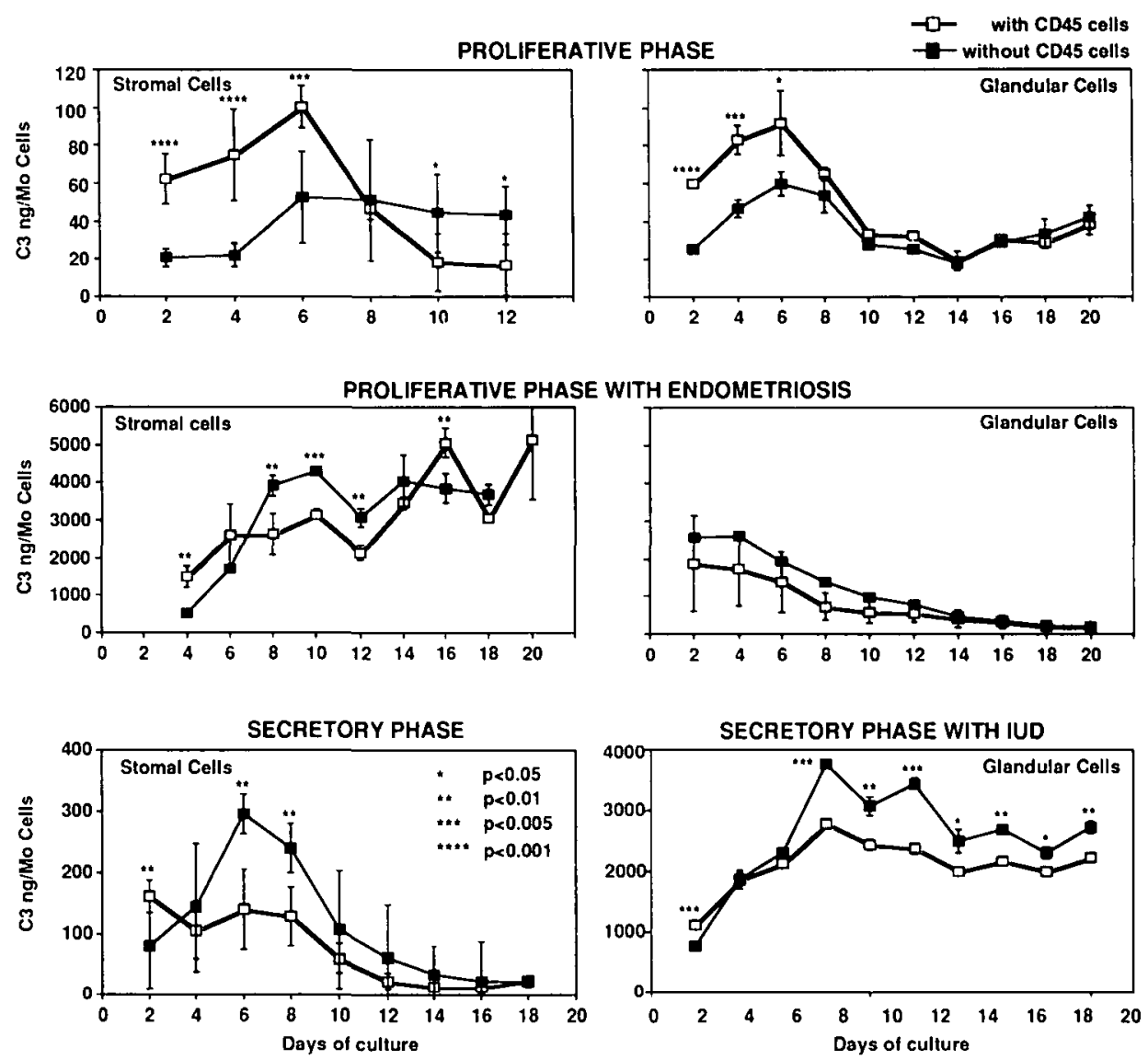

Fig. 5. Effect of immunopurification on endometrial $\mathrm{C} 3$ release by stromal and glandular cells in vitro.

from which the cells came. The same observation was true for glandular cells from secretory endometria bearing an IUD but not for glandular cells of proliferative phases (normal proliferative phase or proliferative phase with endometriosis, Figure 5).

\section{Discussion}

The present immunohistochemical study on normal endometrium confirms two previous reports (Weed and Arquembourg, 1980; Bartosik et al., 1987) that native C3 is present in glandular as well as stromal cells. However, using an antibody to C3d (a split product of C3b), none of these cells were positive for C3 (D'Cruz and Wild, 1992), indicating that intact C3 and not its split products is associated with the endometrial cells. Our study extends these previous observations to an implantation site of an 11 week pregnancy showing that decidual but not extravillous or villous cytotrophoblastic cells are also positive for $\mathrm{C} 3$. Taken together, these results indicate that $\mathrm{C} 3$ is present in stromal as well as glandular cells during the different physiological states an endometrium goes through. Since it is almost impossible on the basis of morphological criteria to distinguish between an endometrial stromal cell and an endometrial lymphomyeloid cell, one cannot exclude that some $\mathrm{C} 3$ was associated with the lymphomyeloid cells colonizing the uterus.

Using the procedure outlined above, the different endometrial cells were separated and purified. The lymphomyeloid cells represented up to $20 \%$ of the stromal cell suspension, the largest proportion of these cells being the large granular lymphocytes and the macrophages (Bulmer et al., 1988). After immunopurification with the anti-CD45 antibody, the stromal and the glandular cell cultures were free of lymphomyeloid elements but were still contaminated by $2-7 \%$ of endothelial and stromal elements in the glandular cell culture and by $1-6 \%$ of endothelial and glandular cells in the stromal cell cultures, a result already reported by us (Martelli et al., 1993). These observations have to be kept in mind before attributing the in-vitro produced $\mathrm{C} 3$ to one cell type.

In presence of cycloheximide $(50 \mu \mathrm{g} / \mathrm{ml})$, the release of C3 by stromal as well as glandular cells was inhibited, indicating that $\mathrm{C} 3$ was produced by glandular and stromal cells and not only released non-specifically. Cycloheximide was not toxic to the cells under our culture conditions since viability checks performed on two different cultures (after 6 and 8 days respectively) did not demonstrate any significant fall in viability (results not shown). These results confirm previous reports (Isaacson et al., 1989, 1990) which showed that $\left.{ }^{35} \mathrm{~S}\right]$ methionine was incorporated into immunoprecipitable C3 mainly by glandular cells but also by stromal elements. In our hands, C3 production by glandular cell preparations obtained from normal endometria, irrespective of the phase of the cycle, was always higher than $\mathrm{C} 3$ production by stromal cells. Furthermore, both cell types produced more $\mathrm{C} 3$ during the secretory phase as compared to the proliferative 
one, but the glandular cells increased their $\mathrm{C} 3$ production much more than the stromal cells. These last observations point to the possibility that in humans, in contrast to the situation in rats, progesterone might be a direct or an indirect (via another endometrial factor) stimulator of endometrial $\mathrm{C} 3$ production. That the production of $\mathrm{C} 3$ by the stromal cell is specific to this cell and is not due to contamination by other cells is shown by (i) stromal C3 production represents one-third to one-tenth of the corresponding glandular cell production, a figure too high to be explained by the $6 \%$ contamination of stromal cell culture by glandular cells; (ii) immunopurified stromal cells, i.e. without lymphomyeloid elements, do release significant amounts of $\mathrm{C} 3$. The fact that during the first 2-6 days of culture the immunopurified endometrial cells produced less $\mathrm{C} 3$ than the nonimmunopurified cells can be explained in two different ways: either endometrial lymphomyeloid cells do produce $\mathrm{C} 3$ under invitro conditions or else they produce factors (cytokines?) which promote glandular and stromal $\mathrm{C} 3$ production. Furthermore, the observation that immunopurified endometrial cells grown in vitro for $>6$ days produced more $\mathrm{C} 3$ than non-immunopurified cells might be explained either by a poor survival of lymphomyeloid cells under our culture conditions or by the secretion by lymphomyeloid cells of factors which inhibit specifically or unspecifically the $\mathrm{C} 3$ production of stromal and glandular cells. It must be said, however, that in these long-term cultures cells might have lost their differentiated function (particularly since they were cultured without hormones). This complicates the interpretation of the results. Unfortunately, no functional marker of endometrial function is readily available to help investigate this aspect. This is why only the first 6 days of culture were considered in Figure 4.

The presence of an IUD in the uterine cavity has a stimulating effect on $\mathrm{C} 3$ production. This production cannot be attributed to inflammatory cells infiltrating the endometrium as a consequence of the presence of the IUD, since the production of $\mathrm{C} 3$ by immunopurified glandular and stromal cells was higher than in the non-immunopurified cells. It is not clear by which mechanism this stimulation of C3 occurs. Eutopic endometria of women with mild endometriosis produce very high levels of C3, an observation already made by others (Bartosik et al., 1987; Isaacson et al., 1989, 1990).

Our study extends these observations by showing that this increase is due to stromal as well as to glandular cells, with little or no contribution of lymphomyeloid elements. What are the factors produced by endometrial implants located in the abdominal cavity which influence the $\mathrm{C} 3$ production of the uterine endometrium? Further investigations are needed to answer this question. However, our results clearly show that the metabolism of the eutopic endometrium is influenced by the ectopic one.

The function of endometrial $\mathrm{C} 3$ can only be speculated, but it is interesting to consider it. According to Bronson and Fusi (1990), peptides containing the Arg-Gly-Asp (RGD) adhesion sequence play a role in spermatozoon-oolemma adhesion. Since C3b contains an RGD sequence (Wright et al., 1987) and since C3 binds to acrosome-reacted spermatozoa (Anderson $e t$ al., 1990), it could be that endometrial C3 is involved in spermatozoon-egg interaction. Alternatively, it could also be that endometrial $\mathrm{C} 3$ is split into $\mathrm{C} 3 \mathrm{a}$ and $\mathrm{C} 3 \mathrm{~b}$ by the presence of a blastocyst, since blastocysts produce proteases (Puistola $e t$ al. , 1989) in the uterine cavity. C3a, a well-known anaphylatoxin, could stimulate the endometrial mast cells to release histamine, which in turn would increase the endometrial vascular permeability in the vicinity of the embryo.

\section{Acknowledgements}

This work was partially supported by grant no 32.29806 .90 from the Swiss National Fund for Scientific Research. The authors wish to thank Mrs Haenggeli for her skilful technical assistance and Miss Gharbi for typing the manuscript.

\section{References}

Anderson,D.J., Wang,H. and Jack,R.M. (1990) A possible role of the complement component $\mathrm{C} 3$ and its receptor, membrane cofactor protein in human sperm/egg interaction. In Program of the 37th Annual Meeting of the Society for Gynecologic Investigation, St Louis, Missouri (Abstract).

Aubert,M. (1977) Radioimmunoassay for human prolactin. In Abraham,G.E. (ed.), Handbook of Radioimmunoassay. Dekker, New York. pp. 179-208.

Bartosik,D., Damjanov,I., Viscarello,R.R. and Riley,J.A. (1987) Immunoproteins in the endometrium: clinical correlates of the presence of complement fractions C3 and C4. Am. J. Obstet. Gynecol., 156, $11-15$

Bischof,P., Germain,G. and Cédard L (1989) Pregnancy associated plasma protein- $A$ in pregnant cynomologus monkeys (Macaca fascicularis): radioimmunoassay, normal levels, effect of RU 486 and preliminary characterization. Biol. Reprod., 40, 853-859.

Bokisch,V.A., Dierich,M.P., Müller-Eberhard,H.J. (1989) Third component of complement (C3): structural properties in relation to function. Proc. Natl. Acad. Sci. USA, 72, 1989-1995.

Bronson,R.A. and Fusi,F. (1990) Evidence that an Arg-Gly-Asp adhesion sequence plays a role in mammalian fertilisation. Biol. Reprod., 43, 1019-1025.

Bulmer,J.N., Lunny,D.P. and Hagin,S.V. (1988) Immunohistochemical characterization of stromal leucocytes in non pregnant human endometrium. Am. J. Reprod. Immunol. Microbiol., 17, 83-90.

Colten,H.R., Strunk,R.C., Perlmutter,D.H. and Cole,F.S. (1986) Regulation of complement protein biosynthesis in mononuclear phagocytes. In Evered,D., Nugent,J. and O'Connor,M. (eds), Cibo Symposium 118: Biochemistry of Macrophages. Pitman Ltd, London, pp. $141-151$.

D'Cruz.O.J. and Wild,R.A. (1992) Evaluation of endometrial tissue specific complement activation in women with endometriosis. Fertil. Steril., 57, 787-795.

Fay,T.N., Lindenberg,S., Teisner,B., Westergaard,L.G., Westergaard,J.G. and Grudzinskas,J.G. (1990) Identification of specific serum proteins synthesized de novo by monolayer cultures of glandular cells of gestational endometrium. Hum. Reprod., 5, $14-18$.

Isaacson,K.B., Coutifaris,C., Garcia,C.R. and Lyttle,C.R. (1989) Production and secretion of complement component 3 by endometriotic tissue. J. Clin. Endocrinol. Metab., 69, 1003-1008.

Isaacson,K.B., Galam,M., Coutifaris,C. and Lyttle,C.R. (1990) Endometrial synthesis and secretion of complement component- 3 by patients with and without endometriosis. Fertil. Steril., 53, 836-841.

Komm,B.S., Rusling,D.J. and Lyttle,C.R. (1986) Estrogen regulation of protein synthesis in the immature rat uterus; the analysis of proteins released into the medium during in-vitro incubation. Endocrinology, 118, 2411-2416.

Kuivanen,P.C., Capulong,R.B., Harkins,R.N. and DeSombre,E.R. (1989) The estrogen responsive $110 \mathrm{~K}$ and $74 \mathrm{~K}$ rat uterine secretory 
proteins are structurally related to complement component C3. Biochem. Biophys. Res. Comm., 158, 898-905.

Martelli,M., Campana,A. and Bischof,P. (1993) Secretion of matrix metalloproteinases by human endometrial cells in vitro. $J$. Reprod. Fertil., 98, 67-76.

Pace,D., Longfellow,M. and Bulmer,J. (1991) Characterization of intraepithelial lymphocytes in human endometrium. J. Reprod. Fertil., 91, 165-174.

Puistola,U., Ronnberg,L., Martikainess,H. and Turpeeniemi-Hujanen,T. (1989) The human embryo produces basement membrane collagen (type IV collagen) degrading protease activity. Hum. Reprod., 4, $309-311$.

Sundstrom,S.A., Komm,B.S., Ponce-de-Leon,H., Yi,Z., Tenscher,C. and Lyttle,C.R. (1989) Estrogen regulation of tissue-specific expression of complement C3. J. Biol. Chem., 264, 16941-16947.

Sundstrom,S.A., Komm,B.S., Xu,Q., Boundy,V. and Lyttle,C.R. (1990) The stimulation of uterine complement component C3 gene expression by antiestrogens. Endocrinology, 126, 1449-1456.

Tauber,P.F., Wettich,W., Nohlen,M. and Zaneveld,L.J.D. (1985) Diffusable proteins of the mucosa of the human cervix, uterus and fallopian tubes: distribution and variations during the menstrual cycle. Am. J. Obstet. Gynecol., 151, 1115-1125.

Vince,G.S., Starkey,P.M., Jackson, M.C., Sargent,I.L., Redman,C.W.G. (1990) Flow cytometric characterization of cell populations in human pregnancy decidua and isolation of decidual macrophages. J. Immunol. Methods, 132, 181-189.

Weed,J.C. and Arquembourg,P.C. (1980) Endometriosis: can it produce an autoimmune response resulting in infertility? Clin. Obstet. Gynecol., 23, 885-893.

Weintraub,J., Bischof,P., Tseng,L., Redard,M. and Vassilakos,P. (1990) CA 125 is an excretory product of human endometrial glands. Biol. Reprod., 42, 721-726.

Wright,S.D., Reddy,P.A., Jong,M.T.C. and Erickson,B. (1987) C3bi receptor (complement receptor type 3 ) recognizes a region of complement C3 containing the sequence Arg-Gly-Asp. Proc. Natl. Acad. Sci. USA, 84, 1965-1968.

Received on November 23, 1993; accepted on May 17, 1994 